\title{
A study on sap flow rate of Mallotusphilippensis and its relationship with environmental factors
}

\author{
T. WATHAM ${ }^{1}$, N.R. PATEL ${ }^{2}$, S.P.S. KUSHWAHA ${ }^{1}$ and V. K. DADHWAL ${ }^{3}$ \\ ${ }^{1}$ Forestry and Ecology Department, ${ }^{2}$ Agriculture and Soil Department, \\ Indian Institute of Remote Sensing, ISRO, Dehradun-248001 \\ ${ }^{3}$ National Remote Sensing Centre, ISRO, Hyderabad-500625 \\ *Corresponding author Email: pnatoo@gmail.com
}

\begin{abstract}
Understating of the water availability and its corresponding use by Mallotusphilippensis and its control by climatic factors can give an idea about the ecosystem interaction. The sap flow measurement taken in M. philippensis during 2014 in Barkot forest showed that,the sap flow rate varied with time of day and season and also with radial depth of the tree trunk. The average daily sap flow rate was found to be $11.5 \pm 1.7 \mathrm{~cm} \mathrm{~h}^{-1}$. Month-wise daily sap flow rate ranged between 4.4 to $10.6 \mathrm{~cm} \mathrm{~h}^{-1}$ in outer portion of the trunk and 12.7 to $17.7 \mathrm{~cm} \mathrm{~h}^{-1}$ in the inner portion of the trunk. Night-time sap flow contributed about 44 per cent of the total annual sap flow. Relative humidity was found to have slightly higher effect on diurnal sap flow rate than air temperature. Monthly sap flow was found to be a function of air temperature. The sap flow rate obtained during this study will be used in augmenting carbon flux studies being carried out in Barkot Flux site (BFS) and can be used in development of canopy conductance and stand transpiration models and validations.
\end{abstract}

Keywords: Barkotflux site (BFS), heat ratio method, keystone species, Mallotusphilippensis, sap flow.

Sap flow measurements provide a powerful tool for quantifying plant water use and monitoring qualitative physiological responses of plants to environmental conditions. Sap flow changes in response to climatic variables, such as intensity of radiation, relative humidity, air temperature, wind speed, rainfall and the soil moisture availability (McDowell et al., 2008), however, the dominating factor varies at different spatio temporal scales (Liu et al., 2012). Uniformity in sap flow rates across the sapwood area are rare (Lu et al., 2000) as age influences wood conducting properties. In earlier research night-time sap flow was regarded insignificant and all the night-time sap flow values were 'corrected' for zero, which led to the underestimation of total flow (Daley and Phillips, 2006). Accurate estimates of whole-tree water use can help in estimation of catchment-level transpiration and also for understanding the contribution of trees to total ecosystem transpiration. Sap flow studies are widely used in validating and comparing the ecosystem level estimates of water use, modelling canopy conductance and stand transpiration (Granier and Breda, 1996; Wang et al., 2014)

Studies on sap flow for several tree species have been carried out in different regions of the world however, from India there are few (Annamalainathan et al., 2013).
M.philippensis grows as sub-dominant, close associate of sal (Shorearobusta) within mixed natural forests as well as managed plantation forests in India. Paine (1966) suggested that M.philippensis can be considered as one of the keystone species of the forests as it is indispensable for providing niches to several under-storey and shade-tolerant species. Understanding the processes and functioning of this species can provide an insight into how the tree component interacts with abiotic component within a particular ecosystem.

The main objectives of the present study was to quantify and understand temporal variation in sap flow rate of M. philippensisand its climatic control in Barkot forest.

\section{MATERIALS AND METHODS}

\section{Study area and climate}

The study was conducted during 2014 in the vicinity of Barkot flux Site (BFS) located in Barkot forest $\left(30^{\circ} 03^{\prime} 52^{\prime \prime}-30^{\circ} 10^{\prime} 43^{\prime \prime} \mathrm{N}\right.$ and $\left.78^{\circ} 09^{\prime} 49^{\prime \prime}-78^{\circ} 17^{\prime} 09^{\prime \prime} \mathrm{E}\right)$. BFS is located almost in the middle Barkot forest at $30^{\circ} 6^{\prime} 44.391$ "N latitude and $78^{\circ} 12^{\prime} 43.06^{\prime \prime}$ E longitude, 415 $\mathrm{m}$ above mean sea level. The study area is relatively flat with slope less than $5^{\circ}$.Monsoon generally begins by third week of June and continues until September. The climate is typical tropical and humid. The temperature ranges between $2^{\circ} \mathrm{C}$ (in 


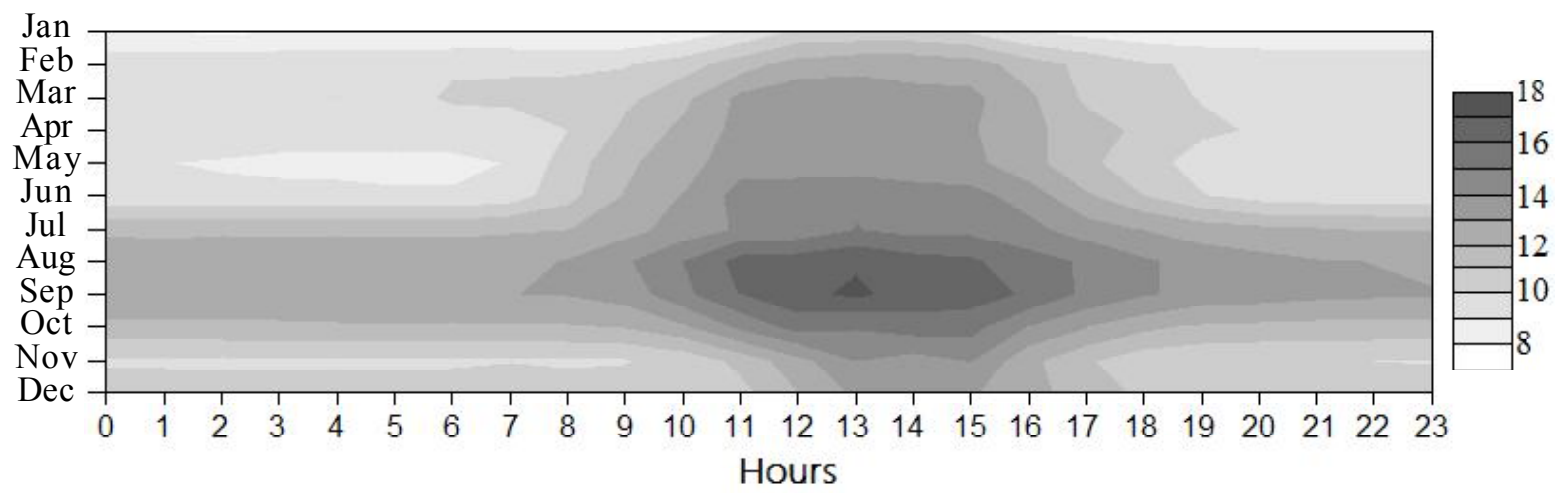

Fig 1: Hourly sap flow rate $\left(\mathrm{cm} \mathrm{h}^{1}\right)$

January) to $41^{\circ} \mathrm{C}$ (in June). According to classification by Champion and Seth (1968), the Barkot forest is covered under Sub-Group 3C, North Indian Tropical Moist Deciduous Forests, forest type being 3C/C2b, Moist Bhabar Dun Sal Forest. Sal (Shorearobusta) is the dominant species. Its typical associates are sain (Terminaliatomentosa), dhauri (Anogeissuslatifolia), and bahera (Terminaliabelerica) in varying proportions. The underwood is generally light and consists of rohini (Mallotusphilippensis), chamror (Ehretialaevis), and amaltas (Cassiafistula).

\section{Meteorological measurements}

Continuous meteorological measurements were made from the various slow sensors mounted at the Barkot flux tower. These data were comprised of hourly average air temperature $(T a)$ and relative humidity $(R h)$ measured at 16 $\mathrm{m}$ height, incoming solar radiation $(R g)$ at $40 \mathrm{~m}$ height, and soil temperature $(T s)$ at $10 \mathrm{~cm}$ depth.

\section{Measurement of sap flow}

For the purpose of this study, a healthy $M$. philippensis tree with $12 \mathrm{~m}$ height and $31.4 \mathrm{~cm}$ over bark girth was selected. Sap flow rate was measured byHeat Ratio Method (HRM) using SFM1 sensor (ICT International Pyt. Ltd). For installation of SFM (Sap flow meter), a patch of bark at breast height (i.e. $1.34 \mathrm{~m}$ above ground) was debarked and installed $3 \mathrm{~cm}$ above the breast height. The SFM1 probes consists of three $35 \mathrm{~mm}$ long needles integrally connected to a 16-bit microprocessor. The top and bottom probes contain two sets of matched and calibrated high precision thermistors located at $7.5 \mathrm{~mm}$ and $22.5 \mathrm{~mm}$ from the tip of each probe. Providing sap flow measurement at 12.5 $\mathrm{mm}\left(\operatorname{Sap}_{\text {Out }}\right)$ and $27.5 \mathrm{~mm}\left(\operatorname{Sap}_{I n}\right)$ depth. The third and centrally located needle is a line heater that runs the full length of the needle to deliver a uniform and exact pulse of heat through the sapwood. The HRM measures the ratio of the increase in temperature following the release of a heat pulse at equidistant points downstream and the upstream from a line heater. The working principle and validation of the SFM1 sensor is documented by Burgess et al. (2001). Standard procedure for installation of the sap flow meter (SFM) was followed. Details of the SFM1 are given in the

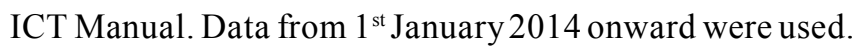
For study on diurnal sap flow rate changes for $M$. philippensis, average $\left(\operatorname{Sap}_{A v g}\right)$ of inner and outer hourly sap flow were taken. Night-time data were separated using $R g<$ $0 \mathrm{Wm}^{-2}$.

\section{RESULTS AND DISCUSSION}

\section{Diurnal and seasonal variation in sap flow velocity}

Diurnal sap flow rate closely followed the course of sun during day. Sapflow rate increased rapidly with increasing $R g$ and touches peak around 1300 hours, then dropped slowly as sunlight fades. Event of lowest diurnal sap flow rate occurred maximum just one hour before midnight (i.e. $2300 \mathrm{hrs}$ ) during our study. Hourly variation in sap flow rate is shown in Fig 1.

Monthly averaged ( $\mathrm{Sap}_{A v g}$, average value of $\mathrm{Sap}_{I n}$ and $\mathrm{Sap}_{\text {Out }}$ ) daily maximum sap flow velocity was found in the month of September with $14.1 \mathrm{~cm} \mathrm{~h}^{-1}$ and minimum was in the month of January with a flow rate of $8.5 \mathrm{~cm} \mathrm{~h}^{-1}$. The flow rate increased gradually from January till March with increase in $T a$ and $R g$. In the month of April and May, the average daily sap flow rate dropped slightly which could be attributed to water stress ( $R h$ was recorded minimum during these months). From June to September, higher $R h$ together with high $T a$ and high intensity of $R g$ remarkably increased the sap flow rate. From October to December, the sap flow rate started decreasing due to decline in the $T a$. The average daily sap flow rate of M. philippensis was found to be 11.5 $\pm 1.7 \mathrm{~cm} \mathrm{~h}^{-1}$ (Table 1). Regression model using $R g, T a$ and $R h$ was found to have coefficient of determinant $\left(\mathrm{R}^{2}\right)$ value of 0.84 .

$\mathrm{Sap}_{A v g}$ flow rate $=-10.05+0.031^{\prime} R g+0.091^{\prime} \mathrm{Ta}+0.15^{\prime} R h$ 
Table 1: Daily average sap flow rate and climatic parameters

\begin{tabular}{lcccccc}
\hline Month & $\mathrm{Sap}_{\text {in }}\left(\mathrm{cm} \mathrm{h}^{-1}\right)$ & $\mathrm{Sap}_{\text {out }}\left(\mathrm{cm} \mathrm{h}^{-1}\right)$ & $\mathrm{Sap}_{\text {avg }}\left(\mathrm{cm} \mathrm{h}^{-1}\right)$ & $\operatorname{Rg}\left(\mathrm{Wm}^{-2}\right)$ & $\operatorname{Ta}\left({ }^{\circ} \mathrm{C}\right)$ & $\operatorname{Rh}(\%)$ \\
\hline Jan & $12.8 \pm 1.1$ & $04.4 \pm 1.7$ & $8.6 \pm 1.3$ & 132.9 & 11.5 & 93.1 \\
Feb & $15.1 \pm 0.5$ & $05.8 \pm 1.1$ & $10.5 \pm 0.6$ & 158.0 & 13.4 & 90.6 \\
Mar & $15.3 \pm 0.5$ & $06.6 \pm 1.0$ & $10.9 \pm 0.5$ & 211.6 & 17.7 & 83.7 \\
Apr & $14.4 \pm 0.5$ & $07.1 \pm 0.7$ & $10.8 \pm 0.4$ & 269.0 & 22.6 & 64.6 \\
May & $12.8 \pm 0.9$ & $08.4 \pm 0.2$ & $10.6 \pm 0.4$ & 278.3 & 26.7 & 60.7 \\
Jun & $13.3 \pm 0.7$ & $08.9 \pm 0.7$ & $11.1 \pm 0.6$ & 261.1 & 28.8 & 75.6 \\
Jul & $16.6 \pm 1.0$ & $08.9 \pm 0.9$ & $12.8 \pm 0.9$ & 168.6 & 26.7 & 97.5 \\
Aug & $17.7 \pm 0.8$ & $10.4 \pm 0.2$ & $14.0 \pm 0.4$ & 199.9 & 26.9 & 98.8 \\
Sep & $17.7 \pm 0.7$ & $10.6 \pm 0.1$ & $14.1 \pm 0.4$ & 205.3 & 25.5 & 98.1 \\
Oct & $16.5 \pm 1.4$ & $09.0 \pm 1.3$ & $12.7 \pm 1.3$ & 180.8 & 21.2 & 97.4 \\
Nov & $14.4 \pm 0.1$ & $07.3 \pm 0.4$ & $10.8 \pm 0.2$ & 168.9 & 15.7 & 97.4 \\
Dec & $14.5 \pm 0.5$ & $07.4 \pm 0.6$ & $10.9 \pm 0.5$ & 139.5 & 11.8 & 95.8 \\
\hline
\end{tabular}

Table 2: Correlation coefficient of various meteorological parameters with $\mathrm{Sap}_{i n}, \mathrm{Sap}_{\text {out }}$, and $\mathrm{Sap}_{\mathrm{avg}}$.

\begin{tabular}{|c|c|c|c|c|c|c|c|c|c|}
\hline $\begin{array}{l}\text { Weather } \\
\text { Parameters }\end{array}$ & $\operatorname{Sap}_{i n}$ & Sap $_{\text {out }}$ & $\operatorname{Sap}_{\text {Avg }}$ & $\operatorname{Sap}_{i n}$ & $\mathrm{Sap}_{\text {out }}$ & $\operatorname{Sap}_{\text {Avg }}$ & $\mathrm{Sap}_{i n}$ & $\mathrm{Sap}_{\text {out }}$ & $S$ a p $\mathrm{Avg}_{\mathrm{A}}$ \\
\hline & \multicolumn{3}{|c|}{ January } & \multicolumn{3}{|c|}{ February } & \multicolumn{3}{|c|}{ March } \\
\hline$T a$ & 0.29 & 0.91 & 0.91 & 0.32 & 0.94 & 0.90 & 0.14 & 0.94 & 0.87 \\
\hline$R h$ & -0.35 & -0.98 & -0.98 & -0.51 & -0.99 & -0.98 & -0.31 & -0.98 & -0.94 \\
\hline$R g$ & 0.20 & 0.74 & 0.74 & 0.74 & 0.69 & 0.76 & 0.59 & 0.85 & 0.91 \\
\hline \multirow[t]{2}{*}{$T s$} & 0.34 & 0.81 & 0.81 & 0.10 & 0.87 & 0.80 & -0.01 & 0.89 & 0.80 \\
\hline & \multicolumn{3}{|c|}{ April } & \multicolumn{3}{|c|}{ May } & \multicolumn{3}{|c|}{ June } \\
\hline$T a$ & 0.59 & 0.93 & 0.92 & -0.47 & 0.91 & 0.88 & 0.33 & 0.93 & 0.91 \\
\hline$R h$ & -0.57 & -0.92 & -0.90 & 0.47 & -0.88 & -0.86 & -0.33 & -0.93 & -0.91 \\
\hline$R g$ & 0.87 & 0.86 & 0.89 & 0.45 & 0.92 & 0.95 & 0.87 & 0.89 & 0.92 \\
\hline \multirow[t]{2}{*}{$T S$} & 0.52 & 0.92 & 0.90 & -0.48 & 0.87 & 0.85 & 0.33 & 0.91 & 0.89 \\
\hline & \multicolumn{3}{|c|}{ July } & \multicolumn{3}{|c|}{ August } & \multicolumn{3}{|c|}{ September } \\
\hline$T a$ & 0.82 & 0.95 & 0.94 & 0.85 & 0.95 & 0.94 & 0.88 & 0.95 & 0.94 \\
\hline$R h$ & -0.89 & -0.99 & -0.98 & -0.97 & -0.95 & -0.95 & -0.96 & -0.94 & -0.94 \\
\hline$R g$ & 0.97 & 0.90 & 0.91 & 0.83 & 0.81 & 0.81 & 0.81 & 0.77 & 0.77 \\
\hline \multirow[t]{2}{*}{$T S$} & 0.76 & 0.92 & 0.91 & 0.80 & 0.91 & 0.90 & 0.84 & 0.92 & 0.91 \\
\hline & \multicolumn{3}{|c|}{ October } & \multicolumn{3}{|c|}{ November } & \multicolumn{3}{|c|}{ December } \\
\hline$T a$ & 0.28 & 0.91 & 0.88 & 0.70 & 0.90 & 0.89 & 0.61 & 0.90 & 0.90 \\
\hline$R h$ & -0.69 & -0.95 & -0.96 & -0.93 & -0.94 & -0.95 & -0.87 & -0.98 & -0.99 \\
\hline$R g$ & 0.82 & 0.65 & 0.71 & 0.70 & 0.70 & 0.70 & 0.65 & 0.65 & 0.65 \\
\hline$T_{S}$ & 0.13 & 0.87 & 0.83 & 0.55 & 0.84 & 0.83 & 0.44 & 0.85 & 0.83 \\
\hline
\end{tabular}

Contribution of night time sap flow

In the present study, significant share of night time sap flow to total sap flow was found (Fig. 1). The night time sap flow was observed to be 44 per cent of the total sap flow. Night -time percentage contribution ranged from 34 per cent to 53 per cent with minimum in the month of June and 

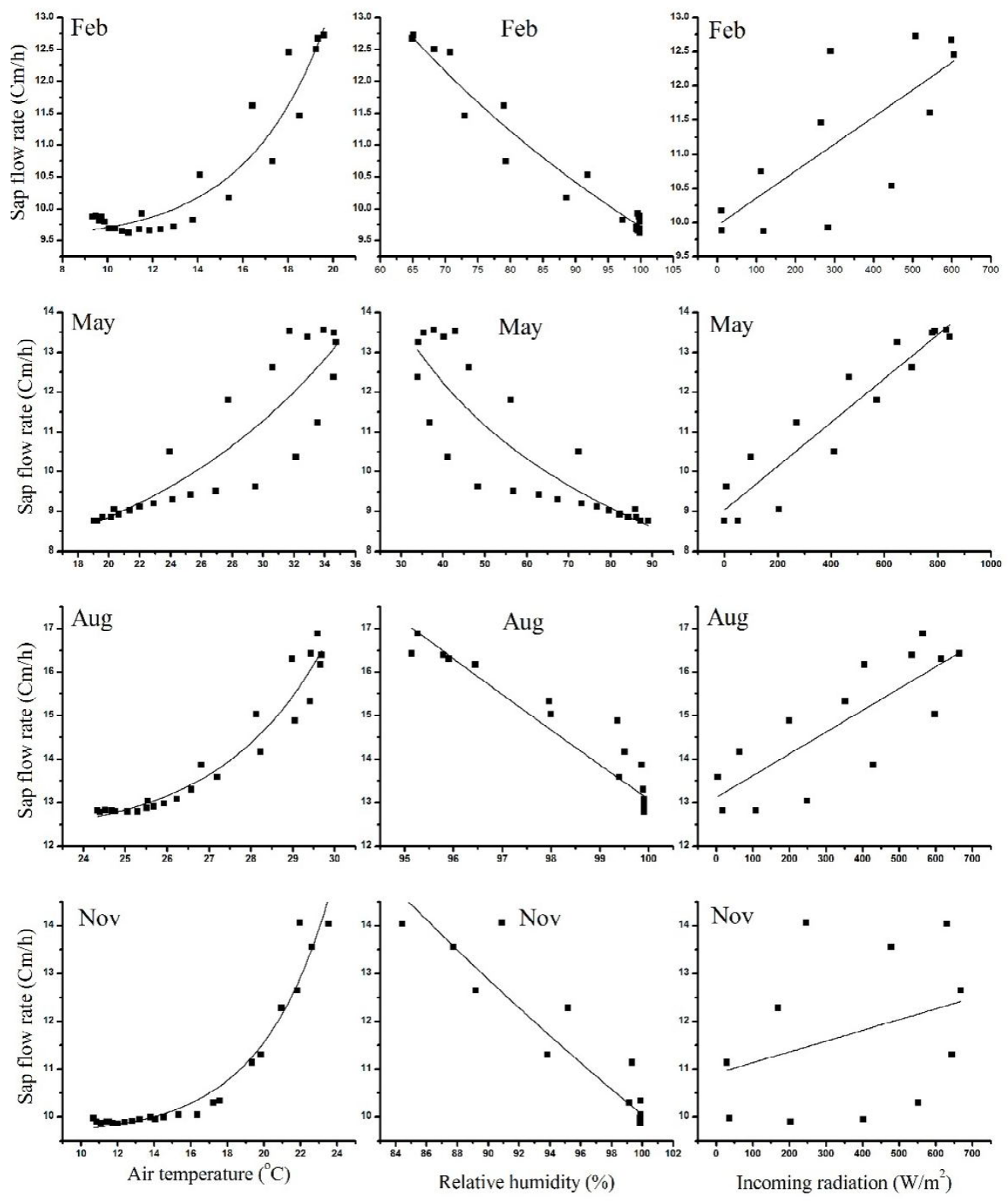

Fig 2: Relationship between diurnal sap flow rate and various environmental parameters

maximum in February month which is little higher as reported by Si et al. (2015) (31\%-47\%) for Populuseuphratica forest but agrees with the report given by Snyder et al. (2003) (30-60\%).

\section{Difference in sap flow rate with different radial depths}

The average monthly sap flow rate at $27.5 \mathrm{~mm}\left(\operatorname{Sap}_{I n}\right)$ depth was always higher as compared to $12.5 \mathrm{~mm}\left(\operatorname{Sap}_{\text {Out }}\right)$ depth (Table 1). On diurnal scale, sap flow rate increased with increase in temperature, sunshine and decrease in moisture. Except in month of May and June, $\mathrm{Sap}_{I n}$ was higher than $\operatorname{Sap}_{\text {out }}$ throughout the day. A phenomenal change was observed in the diurnal sap flow pattern during May-June.
During this period, the $\mathrm{Sap}_{\text {Out }}$ exceeded the $\mathrm{Sap}_{I n}$ on account of the peak temperature and peak sunshine hour i.e. between 1200 to 1700 hours. This change could be attributed to the fact that the outer portion of the trunk is more exposed to the prevailing high air temperature, inducing the outer cells to transpire more.

\section{Influence of meteorological parameters on the sap flow rate}

Hourly observed $T a, R g, R h$ and $T s$ was tested against hourly measured sap flow rate to find out the control of prevailing climatic condition on the diurnal sap flow. $\operatorname{Sap}_{I n} \operatorname{Sap}_{O u t}$ and Sap $\mathrm{P}_{A v g}$ diurnal sap flow rate were correlated with $T a, R h, T s$ and $R g$ (Table 2). 
High correlation coefficient was found with $T a$ and $R h$. Both air and surface temperatures had similar effect on sap flow rate but $T_{s}$ had lesser degree of control over diurnal sap flow rate. The sap flow rate (transpiration) becomes more rapid as $T a$ rises due to steepness of the vapour pressure gradient from plant tissue to air(Tew, 1962).Drier air makes it easier for a plant to release water by transpiration through the stomata on its external surfaces. To determine the nature of relationship between diurnal sap flow and the climatic factors, $\operatorname{Sap}_{A v g}$ was compared against climatic parameters for every month. Increase in Ta was found to have exponential effect on the diurnal sap flow rate, $R h$ had logarithmic relationship with sap flow and $R g$ had linear impact on the sap flow rate. Throughout the year, the monthly $\mathrm{R}^{2}$ value of $T a$ vs. Sap Svg $_{\text {and }} R h$ vs. Sap ${ }_{A v g}$ remained high, ranging between 0.77 to 0.90 and 0.75 to 0.97 respectively.

Fig. 2 shows the relationship of climatic parameters with the diurnal sap flow rate of February, May, August and November months, each representing one season of the year. In case of $R g$, it was observed that the $\mathrm{R}^{2}$ value increased with the increase in $R g$. Highest $\mathrm{R}^{2}$ was found in month of May when the average daily $R g$ was maximum i.e. $278.3 \mathrm{~W} \mathrm{~m}^{-2}$. Very low $\mathrm{R}^{2}$ was noticed in winter months, which can be attributed to the fact that more fraction of the $R g$ is converted to sensible heat and less is available for evapotranspiration. The available solar radiation is used in heating the air (sensible heat), the soil and vegetation, and the remainder used in evapotranspiration process. Wallace and Clum (1938) indicated that enough heat energy is supplied to the leaf by the sun to burn it up if none were dissipated through radiation and cooling by transpiration through stomata. The stomata of most species open upon exposure to light and close in its absence. This accounts to a large extent, for the large difference in transpiration rates between day and night as shown in Fig 1. Opening of stomata in presence of light is explained by osmotic theory. With available light, the osmotic pressure of the guard cells increases as starch is converted to sugar, therefore water moves into the guard cells, increasing their turgor, opening the stomatal aperture. Radiation also accelerating transpiration by heating of the leaves affecting the vapour pressure of water at the leaf surface and partly change the permeability of the protoplasm (Bonner, 1959). It could, therefore, be summarized that the diurnal sap flow rate is primarily controlled by relative humidity and temperature keeping in view the time of the year.

\section{CONCLUSIONS}

The sap flow rate of $M$. philippensis was found to change with time of the day and season. There was difference in sap flow rate radially within the tree. The daily average sap flow rate of $M$. philippensis was found to be $11.5 \pm 1.7 \mathrm{~cm}$ $\mathrm{h}^{-1}$. Night time sap flow contributed about 44 per cent of the total sap flow in M. philippensis.

\section{ACKNOWLEDGEMENTS}

The present work was carried out as part of National carbon project under ISRO-Geosphere biosphere program (IGBP). The authors wish to acknowledge Divisional Forest Officer, Dehradun Forest Division and staff Barkot and Rishikesh Range, Dehradun Forest Division of the Government of Uttarakhand, India for field support.

\section{REFERENCES}

Annamalainathan, K., Joseph, J., Alam, B., Satheesh, P. R. and Jacob, J. (2013). Seasonal changes in xylem sap flow rate in mature rubber plants. J. Plant Crop, 41(3):343-349.

Bonner, J. (1959). Water transport. Sci., 129:447-450.

Burgess, S. S., Adams, M.A., Turner, N. C., Beverly, C. R., Ong, C.K., Khan, A. A. and Bleby, T. M. (2001).An improved heat pulse method to measure low and reverse rates of sap flow in woody plants. Tree Physiol., 21:589-98.

Champion, H. G., and Seth, S. K. (1968). “A Revised Survey of Forest Types of India”, Govt. of India Press, New Delhi.

Daley, M. J. and Phillips, N. G. (2006). Interspecific variation in nighttime transpiration and stomatal conductance in a mixed New England deciduous forest. Tree Physiol., 26:411-419.

Granier,A. and Breda, N.(1996) Modelling canopy conductance and stand transpiration of an oak forest from sap flow measurements. Ann. For. Sci., 53(2-3):537-546.

Liu, H. Z. and Feng, J. W. (2012). Seasonal and interannual variations of evapotranspiration and energy exchange over different land surfaces in a semi-arid area of China. J. Appl. Meteorol. Climatol., 51:1875-1888.

Lu, P., Muller, W. J. and Chacko, E. K. (2000). Spatial variations in xylem sap flux density in the trunk of orchard-grown, mature mango trees under changing soil water conditions. Tree Physiol., 20, 683-692.

McDowell, N. G., White, S. and Pockman, W. T. (2008). 
Transpiration and stomatal conductance across a steep climatic gradient in the southern Rocky Mountains. Ecohydrol.,1, 193-204.

Paine, R. T. (1966). Food web complexity and species diversity. Am. Nat., 100:65-75.

Si, J.H., Feng, Q., Yu, T. F. and Zhao, C. Y.(2015).Nighttime sap flow and itsdriving forces for Populuseuphratica in a desert riparian forest,Northwest, China. J Arid Land, $7: 665-674$

Snyder, K. A., Richards, J. H. and Donovan, L. A. (2003). Nighttime conductance in $\mathrm{C} 3$ and $\mathrm{C} 4$ species: do plants lose water at night?.J. Exp. Bot., 54:861-865.
Tew, R. K. (1962). "Relations between transpiration, leaf temperatures, and some environmental factors". All Graduate Thesis and Dissertations. Paper 2788.

Wallace, R. H. and Clum, H. (1938). Leaftemperatures. Am.J. Bot., 25:83-9.

Wang, H., Guan, H., Deng, Z. and Simmons, C. T. (2014). Optimization of canopy conductance models from concurrent measurements of sap flow and stem water potential on Drooping Sheoak in South Australia. Water Resour. Res., 50:6154-6167. 